\title{
Outbreak
}

\section{An evaluation of knowledge, attitudes, and behaviors of employees of a university hospital in an H1N1 influenza pandemic}

\author{
Omer Evirgen ${ }^{1}$, Nazan Savas ${ }^{2}$, Vicdan Koksaldi Motor ${ }^{1}$, Yusuf Onlen ${ }^{1}$, Erhan Yengil ${ }^{3}$ \\ ${ }^{1}$ Department of Infectious Disease and Clinical Microbiology, Mustafa Kemal University School of Medicine, Hatay, \\ Turkey \\ ${ }^{2}$ Department of Public Health, Mustafa Kemal University School of Medicine, Hatay, Turkey \\ ${ }^{3}$ Department of Family Medicine, Mustafa Kemal University School of Medicine, Hatay, Turkey
}

\begin{abstract}
Introduction: In this study, we aimed to evaluate the knowledge, attitudes, and behaviors concerning the transmission routes of an H1N1 pandemic and the protective measures of health professionals at a university hospital in Turkey.

Methodology: A stratified systematic sampling method was used to select the sample size of the study group. A total of 22 professors, 29 researchers, and 26 nurses were included in the study.

Results: The mean scores of the individuals were $8.4 \pm 2.5$ (over 20) for knowledge about H1N1 transmission, $27.6 \pm 4.0$ (over 60 ) for knowledge about protection against H1N1, 25.8 \pm 4.2 (over 45) for correct or appropriate attitudes, and $33.6 \pm 8.9$ (over 60) for correct behaviors. A negative correlation between total knowledge and behavior was found $(\mathrm{p}<0.001, \mathrm{r}=-0.543)$.

Conclusions: In epidemics, standard protection measures should be known and applied. Regarding this topic, the web page of the Ministry of Health comes to the forefront as a reliable source of information in addition to scientific explanations.
\end{abstract}

Key words: H1N1 virus; influenza vaccine; health professional; health knowledge; attitudes; behaviors.

J Infect Dev Ctries 2014; 8(5):561-569. doi:10.3855/jidc.3400

(Received 11 February 2013 - Accepted 02 December 2013)

Copyright (C) 2014 Evirgen et al. This is an open-access article distributed under the Creative Commons Attribution License, which permits unrestricted use, distribution, and reproduction in any medium, provided the original work is properly cited.

\section{Introduction}

Influenza is an acute infectious disease associated with fever and respiratory tract symptoms. Over the last 400 years, it has caused epidemics recurring in one- to three-year periods [1]. Since the last influenza outbreak in Hong Kong in 1968, which also caused pandemic, an outbreak arose in pigs in Mexico in March 2009; the World Health Organization (WHO) proclaimed the disease to be a pandemic phase six on 11 June 2009 [2,3]. Influenza was transmitted from pigs to humans and reached the respiratory tract. The disease spread among humans, especially in USA and Canada, and became an epidemic, affecting all countries in the world until March 2010 [4]. In our country, the outbreak was most severe in the period between November and December of 2009 was the time when it was most effective [5].

It is very important to know what the transmission routes of infectious diseases are and thereby accordingly take self-protective measures against epidemic diseases. Measures such as contact, droplet, and air route isolation methods (or a combination of the three) are used to prevent disease transmission to other patients, visitors, or health professionals. The 2007 Health Care Infection Control Practices Advisory Committee (HICPAC) recommends the use of standard and droplet route isolation to prevent influenza transmission [6].

Health professionals must be at their workplaces even if their health is at risk. Nevertheless, they should also protect their health while they are treating patients [7]. For this reason, the training of health professionals is a dynamic process, and continuous in-service training is necessary. Especially in cases of outbreaks, accurate information sources are important. Presently, visual and written media, conferences, medical journals, internet and social networks are main sources of information [8].

In this study, we aimed to evaluate the knowledge, attitudes, and behaviors concerning the transmission routes of an $\mathrm{H} 1 \mathrm{~N} 1$ pandemic and the protection measures adopted by health professionals of a university hospital serving as tertiary care in Hatay, Turkey. 


\section{Methodology}

Study environment and size

The study environment consisted of 358 health professionals working in Hatay Mustafa Kemal University Medical Faculty Research and Application Hospital in February 2010. Hatay is in the northern Mediterranean region. In their study, Rubin et al. found that the percentage of health professionals changing their behaviors due to swine flu was $37.8 \%$ [9]. In the calculation of the sample size to be selected for our study, the $37.8 \%$ prevalence, $90 \%$ confidence interval, and $10 \%$ deviation obtained as a result of Rubin et al.'s study were used, and the sample size was calculated to be 72 .

\section{Selection of samples}

The stratified systematic sampling method was used in the selection of samples. The employees of the hospital were divided into four strata according to the departments in which they were working - internal medicine, surgery, the operation room/intensive care unit, and laboratory. The health professionals from all strata were listed as professors, medical research assistants, and nurses. Of the 358 health professionals included in the study, $128(35 \%)$ were from surgical departments, 118 (32\%) were from internal medicine, $61(17 \%)$ were from the operation room/intensive care unit, and 51 were (14\%) were from laboratories. Seventy-seven individuals who were going to be sampled were distributed to the strata as 29 from surgical, 26 from internal medicine, 13 from the operation room/intensive care unit, and 9 from laboratory departments according to the weight of strata. Subsequently, professors, medical research assistants, and nurses to be selected from each stratum were taken to the sample group by distribution according to their weights. Accordingly, a total of 22 professors, 29 medical research assistants, and 26 nurses were included in the study.

\section{Questionnaire}

The study group was surveyed to determine their socio-demographic and business characteristics and their knowledge, attitudes, and behaviors concerning swine flu. The questionnaire was administered face-toface in workplaces. Socio-demographic and business life characteristics were surveyed with 19 questions, whereas knowledge, attitudes, and behaviors concerning swine flu were surveyed with 16, 9, and 12 questions, respectively. Among the questions about knowledge levels, 4 questions were about transmission, whereas 12 were about protection.
Moreover, the reasons for not vaccinating were surveyed with four questions that were part of the attitude questions; however, they did not participate in the scoring. The total number of questions about knowledge, attitudes, and behaviors concerning swine flu was 41 . A total of 37 questions were scored. The answers to knowledge and attitudes questions were on a five-point Likert-type scale (absolutely accept, accept, not sure, do not accept, and absolutely do not accept), whereas the answers to behavior questions were either no or yes. For the five-point Likert-type answers, the scores between one and five were assigned. The no and yes answers were scored as 0 and 5 , respectively. Accordingly, each person could score a maximum of 20,60,45, and 60 for knowledge level regarding transmission (4 questions), knowledge level regarding protection (12 questions), attitudes (9 questions), and behaviors (12 questions), respectively. The maximum total score was 185 (37 questions).

\section{Statistical analysis}

According to the socio-demographic characteristics of the study group, the significance of the differences between the average scores for knowledge, attitudes, and behaviors concerning swine flu was analyzed using Whitney-U, Kruskal Wallis, and correlation tests. The difference between being or not being vaccinated was evaluated using the Chisquared test. A value of less than 0.05 was considered statistically significant. Statistical analysis was performed by using SPSS version 15.0.

\section{Results}

Among the individuals of the study group, the youngest was 19 , the oldest was 48 , and the average age was $31.95 \pm 6.19$. The percentages of men and women were $40.3 \%(n=31)$ and $59.7 \%(n=46)$, respectively. Furthermore, 29 (35\%) individuals were from surgical departments, $26(32 \%)$ were from internal medicine departments, $13(17 \%)$ were from the operation room/intensive care unit, and 9 individuals $(14 \%)$ were from laboratories. When they were evaluated according to their duties, 22 were professors, 29 were researchers, and 26 were nurses.

The average scores of the study group from the questionnaire about knowledge, attitudes, and behaviors concerning H1N1 were, 36.0 \pm 5.0 (from 80) for average $\mathrm{H} 1 \mathrm{~N} 1$ general knowledge, $8.4 \pm 2.5$ (from 20) for $\mathrm{H} 1 \mathrm{~N} 1$ transmission, $27.6 \pm 4.0$ (from 60) for protecting from $\mathrm{H} 1 \mathrm{~N} 1,25.8 \pm 4.2$ (from 45) for right attitude, and 33.6 \pm 8.9 (from 60 ) for right behavior. A negative correlation was detected between total 
knowledge and behavior ( $\mathrm{p}<0.001, \mathrm{r}=-0,543$ ) (Table 1).

When the average scores for knowledge, attitudes, and behaviors were compared according to the sociodemographic characteristics of the study group, gender, marriage, pregnancy of the individual or his wife, having a chronic disease, the presence of an elder or a child attending school/kindergarten at home, the department at work, and the department where the individual spend most of the time did not affect the average knowledge, attitude, and behavior scores for H1N1 ( $p>0.05)$ (Table 2). The differences between the total scores of professors, researchers, and nurses for H1N1 knowledge $(\mathrm{p}<0.01)$, attitude $(\mathrm{p}<0.01)$, and behavior were detected $(p<0.01)$. Nurses had the highest average score for knowledge, whereas professors had the average highest score for positive attitudes and behaviors. Moreover, the average score for positive behaviors was higher for individuals who had babies at home compared to those who did not ( $\mathrm{p}$ $<0.05)$. Using public transportation to get to work did not have an effect on knowledge, attitude, and behavior scores for H1N1 ( $p>0.05)$.

The awareness of the study group on the situation of the H1N1 infection into the hospital did not affect their knowledge, attitudes, and behaviors $(p>0.05)$ (Table 3). Responses given to the questions measuring knowledge (questions 1-16) are summarized in Table 4. The answers given by the study group to questions 17-29 surveying the attitudes for H1N1 are shown in Table 5. According to this table, $55 \%$ of health professionals worried about working in a dangerous environment; $63.7 \%$ of them thought that they were under risk; $42.9 \%$ of them were not sure that a surgical mask would protect them, and $37.7 \%$ of them did not believe that a surgical mask would protect them; $22.1 \%$ did not believe that washing hands with soap would protect them, and $27.3 \%$ were unsure; $92.3 \%$ believed that they would carry H1N1 from the hospital to their homes; $50.6 \%$ believed there was a risk for neurological diseases due to the vaccine; $29.9 \%$ considered the disease less dangerous than the vaccine, and; $42.9 \%$ believed that this pandemic was a scenario created by pharmaceutical companies. Moreover, $22.1 \%$ of health professionals also did not trust other vaccines.

Within the study group, 36 (46.8\%) individuals were vaccinated and 41 (53.2\%) were not. When asked about their reasons for not vaccinating (questions 2629 ), $46.4 \%$ of them (19) did not believe in the efficacy of the vaccine, and $29.3 \%$ (12) were not vaccinated because the Prime Minister was not vaccinated. A total of $24.4 \%$ (10) of the individuals stated that they would be vaccinated if the vaccine would not include thiomersal as a preservative, whereas $22 \%$ of respondents (9) stated that they would be vaccinated if there was no adjuvant substance in the vaccine (Table $5)$. Among the individuals who were not vaccinated, $46.4 \%$ (19) considered the vaccine to be more dangerous than being infected with $\mathrm{H} 1 \mathrm{~N} 1$, whereas $56 \%$ (23) of them thought that the pandemic was a scenario created by pharmaceutical companies. Moreover, $77.3 \%$ (17) of the professors, $37.9 \%$ (11) of the researchers, and $30.8 \%$ (8) of the nurses were not vaccinated. This difference between the groups was found to be statistically significant $(p<0.05)$. When asked about their sources of information about H1N1, $27.3 \%$ of the professors named scientific letters, $27.6 \%$ of the researchers named seminars and conferences, and $30.8 \%$ of the nurses named the web page of the Ministry of Health as their most-used sources (Table 6). The most commonly used information source was the web page of the Ministry of Health.

The behaviors of the study group during the pandemic are shown in Table 7. Accordingly, cleaning the environment airfiltering of the air in the hospital, washing hands after examination, and using hand antiseptics were actions performed by most of the health professionals to protect against H1N1. Within the last three months, the vaccine was recommended by most of the health professionals to at-risk groups. Nevertheless, medicines supporting the immune system, alternative medicine drugs, and antivirals were not preferred by most of the health professionals within the last three months.

\section{Discussion}

University hospitals are not only potential severe epidemic centers during a pandemic, but are also important supporting factors in terms of public health. For this reason, it is important to learn the knowledge, attitudes, and behaviors of health professionals concerning the pandemic.

It has been shown in previous studies that the most important sources used to inform the public about a pandemic are mass communication tools [10,11]. When Akan et al. surveyed students studying health sciences, $19.9 \%$ of the students reported the internet as their main source of information about H1N1 pandemics, $8 \%$ reported health professionals, and $72.1 \%$ reported the media. 
Table 1. Knowledge, attitude, and behavior scores about H1N1 of the health professionals working at the university hospital after the pandemic $(\mathrm{N}=77)$

\begin{tabular}{ccccccc}
\hline Score & Knowledge & Knowledge & Knowledge \\
Transmission & General & Knowledge & Total & Attitude \\
\hline Mean \pm SD & $8.4 \pm 2.5$ & $27.6 \pm 4.0$ & $36.0 \pm 5.0$ & $72.0 \pm 10.0$ & $25.8 \pm 4.2$ & $33.6 \pm 8.9$ \\
Min-max & $4-5$ & $19-38$ & $26-46$ & $52-92$ & $13-37$ \\
On score & 20 & 60 & 80 & 160 & $45-50$ & 60 \\
\hline
\end{tabular}

Table 2. Knowledge, attitude, and behavior scores for H1N1 according to the socio-demographic factors of the health professionals working at the university hospital

\begin{tabular}{|c|c|c|c|c|c|c|}
\hline Socio-demographic factors & $\begin{array}{l}\text { Knowledge } \\
\text { Mean } \pm \text { SD }\end{array}$ & $\mathrm{p}$ & $\begin{array}{c}\text { Attitude } \\
\text { Mean } \pm \text { SD }\end{array}$ & $\mathrm{p}$ & $\begin{array}{c}\text { Practice } \\
\text { Mean } \pm \text { SD }\end{array}$ & $\mathrm{p}$ \\
\hline $\begin{array}{l}\text { Sex } \\
\text { Male }(n=31) \\
\text { Female }(n=46)\end{array}$ & $\begin{array}{l}35.5 \pm 4.1 \\
36.4 \pm 5.5\end{array}$ & $\mathrm{p}>0.05$ & $\begin{array}{l}26.8 \pm 4.6 \\
25.2 \pm 3.9\end{array}$ & $\mathrm{p}>0.05$ & $\begin{array}{l}33.9 \pm 8.3 \\
33.4 \pm 1.5\end{array}$ & $\mathrm{p}>0.05$ \\
\hline $\begin{array}{l}\text { Marital status } \\
\text { Single }(n=26) \\
\text { Married }(=51)\end{array}$ & $\begin{array}{l}36.7 \pm 5.6 \\
35.7 \pm 4.6\end{array}$ & $\mathrm{p}>0.05$ & $\begin{array}{l}25.1 \pm 2.7 \\
26.2 \pm 4.8\end{array}$ & $\mathrm{p}>0.05$ & $\begin{array}{l}31.1 \pm 6.5 \\
34.6 \pm 9.5\end{array}$ & $\mathrm{p}>0.05$ \\
\hline $\begin{array}{l}\text { Children in your house } \\
\text { Absent }(n=40) \\
\text { Present }(n=37)\end{array}$ & $\begin{array}{l}36.6 \pm 5.5 \\
35.4 \pm 4.4\end{array}$ & $\mathrm{p}>0.05$ & $\begin{array}{l}25.6 \pm 3.2 \\
26.1 \pm 5.2\end{array}$ & $\mathrm{p}>0.05$ & $\begin{array}{l}31.0 \pm 7.8 \\
35.6 \pm 9.2\end{array}$ & $\mathrm{P}<0.05$ \\
\hline $\begin{array}{l}\text { Currently ill } \\
\text { Absent }(n=74) \\
\text { Present }(n=3)\end{array}$ & $\begin{array}{l}35.9 \pm 5.0 \\
38.6 \pm 5.5\end{array}$ & $\mathrm{p}>0.05$ & $\begin{array}{l}25.8 \pm 4.3 \\
27.3 \pm 4.0\end{array}$ & $\mathrm{p}>0.05$ & $\begin{array}{l}33.7 \pm 9.1 \\
33.3 \pm 5.7\end{array}$ & $\mathrm{p}>0.05$ \\
\hline $\begin{array}{l}\text { Workplace } \\
\text { Internal departments }(n=26) \\
\text { Surgical departments }(n=29) \\
\text { Operating theatre }(n=13) \\
\text { Laboratory }(n=9)\end{array}$ & $\begin{array}{l}34.6 \pm 4.9 \\
36.0 \pm 4.1 \\
37.7 \pm 4.7 \\
37.8 \pm 7.2\end{array}$ & $\mathrm{p}>0.05$ & $\begin{array}{l}26.9 \pm 4.6 \\
26.0 \pm 4.3 \\
23.8 \pm 3.5 \\
25.5 \pm 3.5\end{array}$ & $\mathrm{p}>0.05$ & $\begin{array}{c}35.2 \pm 8.8 \\
32.7 \pm 9.5 \\
31.2 \pm 5.2 \\
36.2 \pm 11.5\end{array}$ & $\mathrm{p}>0.05$ \\
\hline $\begin{array}{l}\text { Assignment } \\
\text { Lecturer }(n=22) \\
\text { Assistant }(n=29) \\
\text { Nurse }(n=26)\end{array}$ & $\begin{array}{l}33.7 \pm 3.5 \\
35.4 \pm 5.4 \\
38.6 \pm 4.4\end{array}$ & $\mathrm{p}<0.01$ & $\begin{array}{l}28.1 \pm 4.4 \\
25.5 \pm 3.9 \\
24.4 \pm 3.9\end{array}$ & $\mathrm{p}<0.01$ & $\begin{array}{l}38.6 \pm 7.4 \\
30.4 \pm 9.2 \\
31.8 \pm 8.2\end{array}$ & $\mathrm{p}<0.01$ \\
\hline $\begin{array}{l}\text { Transport to hospital } \\
\text { Car }(n=46) \\
\text { Public transportation }(n=29)\end{array}$ & $\begin{array}{l}35.3 \pm 4.7 \\
37.2 \pm 5.3\end{array}$ & $\mathrm{p}>0.05$ & $\begin{array}{l}26.7 \pm 4.8 \\
24.6 \pm 3.0\end{array}$ & $\mathrm{p}<0.05$ & $\begin{array}{l}33.5 \pm 9.3 \\
34.4 \pm 8.2\end{array}$ & $\mathrm{p}>0.05$ \\
\hline
\end{tabular}


Table 3. Knowledge, attitude, and behavior scores based on the awareness on $\mathrm{H} 1 \mathrm{H} 1$ infection of health professionals working at the university hospital

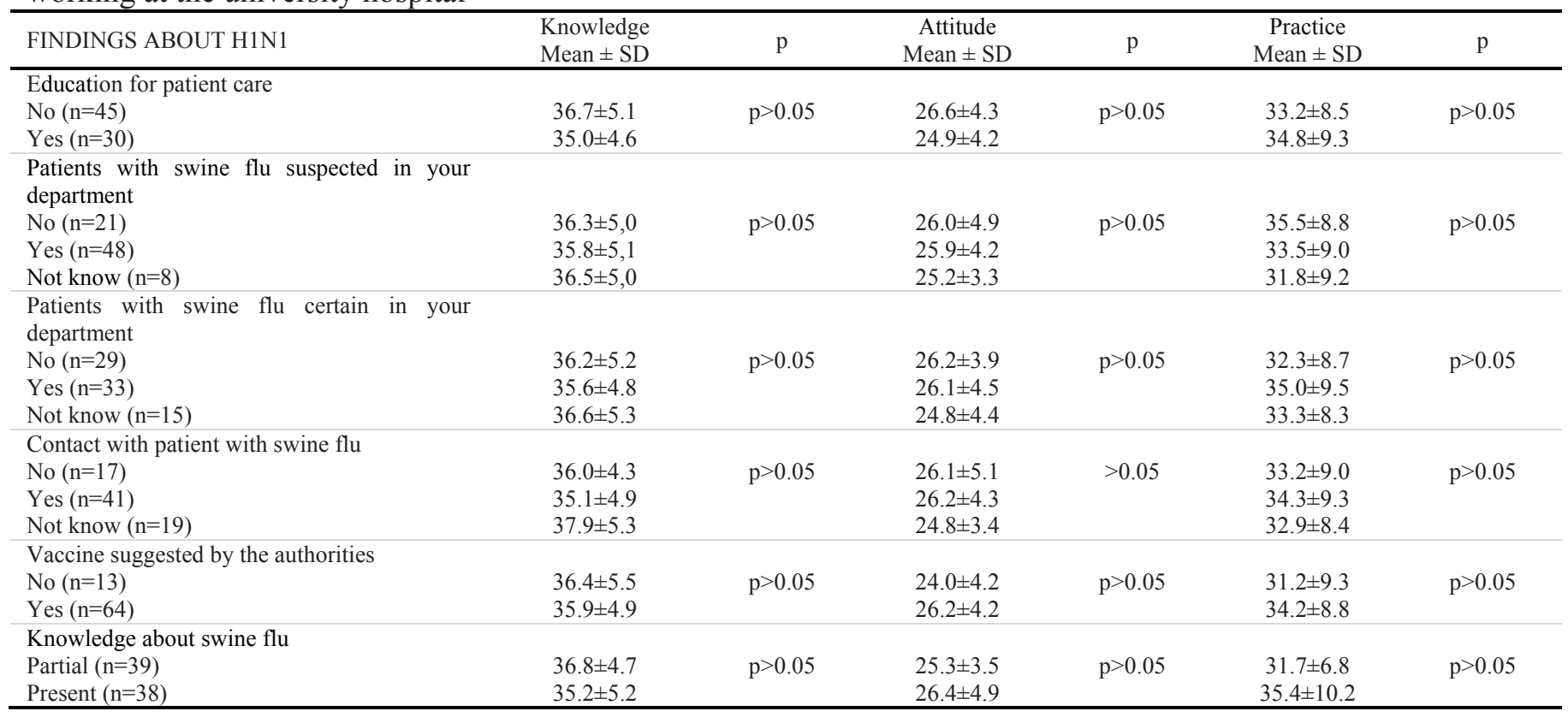

Table 4. Responses given to the questions measuring attitudes (17-29)

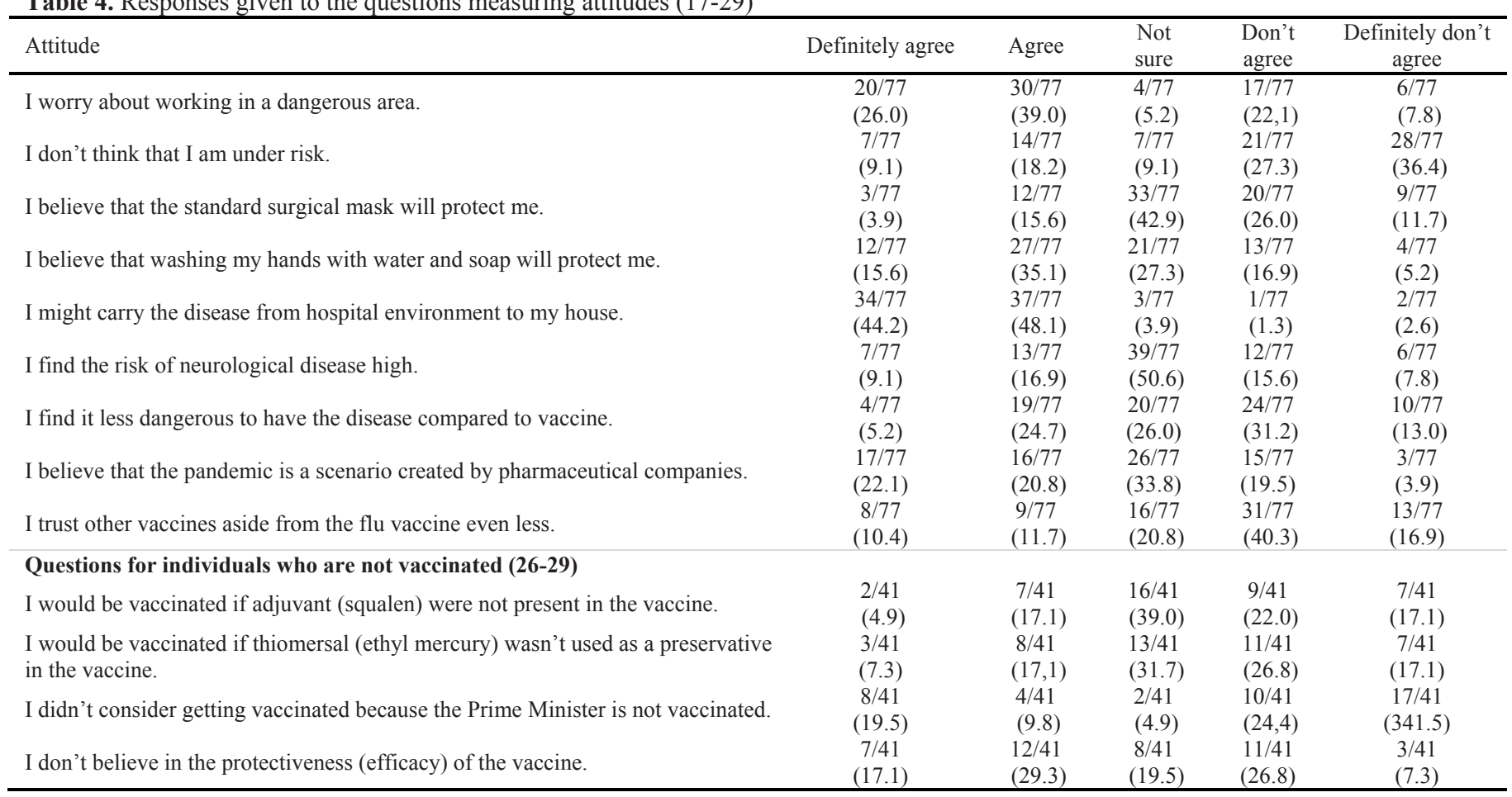

Values were expressed as \% of the participants. 
Table 5. Information sources about H1N1 most commonly used by health professionals working at the university hospital

\begin{tabular}{|c|c|c|c|c|c|}
\hline Most-used information sources & Professors & Researchers & Nurses & Total & $(\%)$ \\
\hline Newspaper/magazine & - & 2 & 5 & 7 & 9.1 \\
\hline TV/radio & 5 & 4 & 6 & 15 & 19.5 \\
\hline Colleagues & 5 & 3 & 6 & 14 & 18.2 \\
\hline Total & 22 & 29 & 26 & 77 & 100 \\
\hline
\end{tabular}

Table 6. Health professional's responses given to the questions measuring behaviors.

\begin{tabular}{|c|c|c|}
\hline Behavior & $\begin{array}{c}\text { Yes } \\
\mathrm{N}(\%)\end{array}$ & $\begin{array}{c}\text { No } \\
\text { N (\%) }\end{array}$ \\
\hline Today, I washed my hands with soap after practice. & $69(89.6)$ & $8(10.4)$ \\
\hline Today, I rubbed my hands with hand antiseptic after practice. & $39(50.6)$ & $38(49.4)$ \\
\hline I have been vaccinated for swine flu. & $36(46.8)$ & $41(53.2)$ \\
\hline I had my children vaccinated. & $16(20.8)$ & $49(63.6)$ \\
\hline I recommended vaccination to at-risk groups within the last three months. & $41(53.2)$ & $36(46.8)$ \\
\hline I used an antiviral product for prophylactic purposes within the last three months. & $4(5.2)$ & $73(94.8)$ \\
\hline I followed the scientific journals about H1N1 within the last three months. & $43(55.8)$ & $34(44.2)$ \\
\hline I saw the statements on media about the pandemic within the last three months. & $60(77.9)$ & $17(22.1)$ \\
\hline
\end{tabular}

Table 7. Responses given to the questions measuring knowledge (1-16)

\begin{tabular}{|c|c|c|c|c|c|c|}
\hline Knowledge & $\begin{array}{c}\text { Definitely } \\
\text { agree }\end{array}$ & Agree & Not sure & $\begin{array}{l}\text { Don't } \\
\text { agree }\end{array}$ & $\begin{array}{c}\text { Definitely } \\
\text { don't agree }\end{array}$ & $\begin{array}{l}\text { Didn't } \\
\text { answer }\end{array}$ \\
\hline Directly through droplet that is spread by sneezing and coughing & $\begin{array}{l}62 / 77 \\
(80.5)\end{array}$ & $\begin{array}{l}14 / 77 \\
(18.2)\end{array}$ & $\begin{array}{l}1 / 77 \\
(1.3)\end{array}$ & - & - & - \\
\hline Touchıng patient with hands & $\begin{array}{l}41 / 77 \\
(53.2)\end{array}$ & $\begin{array}{l}24 / 77 \\
(31.2)\end{array}$ & $\begin{array}{c}8 / 77 \\
(10.4)\end{array}$ & $\begin{array}{l}3 / 77 \\
(3.9)\end{array}$ & $\begin{array}{l}1 / 77 \\
(1.3)\end{array}$ & - \\
\hline Contact with blood & $\begin{array}{l}11 / 77 \\
(14.3)\end{array}$ & $\begin{array}{c}8 / 77 \\
(10.4)\end{array}$ & $\begin{array}{l}22 / 77 \\
(28.6)\end{array}$ & $\begin{array}{l}25 / 77 \\
(32.5)\end{array}$ & $\begin{array}{l}10 / 77 \\
(13.0)\end{array}$ & $\begin{array}{l}1 / 77 \\
(1.3)\end{array}$ \\
\hline \multicolumn{7}{|l|}{ Knowledge prevention } \\
\hline Ventilation of indoor environment & $\begin{array}{l}67 / 77 \\
(87.0)\end{array}$ & $\begin{array}{c}9 / 77 \\
(11.7)\end{array}$ & $\begin{array}{l}1 / 77 \\
(1.3)\end{array}$ & - & - & - \\
\hline Disinfection of air with ultraviolet & $\begin{array}{l}36 / 77 \\
(46.8)\end{array}$ & $\begin{array}{l}13 / 77 \\
(16.9)\end{array}$ & $\begin{array}{l}17 / 77 \\
(22.1)\end{array}$ & $\begin{array}{c}8 / 77 \\
(10.4)\end{array}$ & $\begin{array}{l}3 / 77 \\
(3.9)\end{array}$ & - \\
\hline İt is enough to clean surface with water and detergent & $\begin{array}{l}25 / 77 \\
(32.5)\end{array}$ & $\begin{array}{l}26 / 77 \\
(33.8)\end{array}$ & $\begin{array}{l}15 / 77 \\
(19.5)\end{array}$ & $\begin{array}{c}9 / 77 \\
(11.7)\end{array}$ & $\begin{array}{l}1 / 77 \\
(1.3)\end{array}$ & $\begin{array}{l}1 / 77 \\
(1.3)\end{array}$ \\
\hline $\begin{array}{l}\text { İt is enough to wash your hands with water and soap after touching patient and } \\
\text { his/her belongings }\end{array}$ & $\begin{array}{l}29 / 77 \\
(37.7)\end{array}$ & $\begin{array}{l}30 / 77 \\
(39.0)\end{array}$ & $\begin{array}{l}13 / 77 \\
(16.9)\end{array}$ & $\begin{array}{l}5 / 77 \\
(6.5)\end{array}$ & - & - \\
\hline $\begin{array}{l}\text { İt is necessary to clean your hands with antiseptic after touching patient and } \\
\text { his/her belongings }\end{array}$ & $\begin{array}{l}32 / 77 \\
(41.6)\end{array}$ & $\begin{array}{l}33 / 77 \\
(42.9)\end{array}$ & $\begin{array}{l}6 / 77 \\
(7.8)\end{array}$ & $\begin{array}{l}4 / 77 \\
(5.2)\end{array}$ & $\begin{array}{l}2 / 77 \\
(2.6)\end{array}$ & - \\
\hline Puttıng on glove & $\begin{array}{l}43 / 77 \\
(55.8)\end{array}$ & $\begin{array}{l}24 / 77 \\
(31.2)\end{array}$ & $\begin{array}{l}6 / 77 \\
(7.8)\end{array}$ & $\begin{array}{l}2 / 77 \\
(2.6)\end{array}$ & $\begin{array}{l}2 / 77 \\
(2.6)\end{array}$ & - \\
\hline Use antiviral drugs for prophylaxis & $\begin{array}{l}6 / 77 \\
(7.8)\end{array}$ & $\begin{array}{l}21 / 77 \\
(27.3)\end{array}$ & $\begin{array}{l}19 / 77 \\
(24.7)\end{array}$ & $\begin{array}{l}19 / 77 \\
(24.7)\end{array}$ & $\begin{array}{l}12 / 77 \\
(15.6)\end{array}$ & - \\
\hline Vaccination of health workers & $\begin{array}{l}21 / 77 \\
(27.3)\end{array}$ & $\begin{array}{l}28 / 77 \\
(36.4)\end{array}$ & $\begin{array}{l}17 / 77 \\
(22.1)\end{array}$ & $\begin{array}{c}8 / 77 \\
(10.4)\end{array}$ & $\begin{array}{l}3 / 77 \\
(3.9)\end{array}$ & - \\
\hline Taking a medicine that is called alternative medicine (herbal medicine) & $\begin{array}{l}4 / 77 \\
(5.2)\end{array}$ & $\begin{array}{l}16 / 77 \\
(20.8)\end{array}$ & $\begin{array}{l}26 / 77 \\
(33.8)\end{array}$ & $\begin{array}{l}19 / 77 \\
(24.7)\end{array}$ & $\begin{array}{l}11 / 77 \\
(14.3)\end{array}$ & $\begin{array}{l}1 / 77 \\
(1.3)\end{array}$ \\
\hline Taking a medicine that supports immune system & $\begin{array}{l}4 / 77 \\
(5.2) \\
\end{array}$ & $\begin{array}{l}18 / 77 \\
(23.4)\end{array}$ & $\begin{array}{l}33 / 77 \\
(42.9)\end{array}$ & $\begin{array}{l}16 / 77 \\
(20.8)\end{array}$ & $\begin{array}{l}6 / 77 \\
(7.8) \\
\end{array}$ & - \\
\hline
\end{tabular}


The use of the internet as an information source was significantly higher in students studying health sciences compared to students studying other subjects [12]. Azap et al. found that the most frequently used sources were scientific letters or journals, conferences in the hospital, and scientific announcements on TV, whereas Torun et al. determined that visual and written media were the most commonly used sources of information among health professionals [13,14]. In our study, we found that, according to their statements, professors used scientific letters, researchers used seminar and conferences, and nurses mostly used the web page of the Ministry of Health as their sources of information for H1N1. The overall most commonly used source of information for health professionals was the web page of the Ministry of Health. When we consider that scientific letters and journals are accessed through the internet in general, it is obvious that the most important communication tool for health professionals is the internet. Besides this, the fact that the researchers prefer conferences and seminars as sources of information suggests that they spend less time reading.

Torun et al. did not report a significant difference between health professionals who had children between 6 and 18 months of age and health professionals without children in terms of vaccination ratios [13]. We also could not find a relationship between vaccination and having children. However, the behavior scores of health professionals with children were significantly higher than the scores of health professionals without children $(\mathrm{p}<0.01)$. In general, $92.3 \%$ of the study group worried that they would carry the disease to their homes. Among the health professionals with children, this had a positive effect on their behaviors, whereas this effect was not present in others. This fact made us think that the worry about bringing the disease home and the instinct to protect their children from the disease may have a positive effect on behaviors of health professionals who have children at home.

In a previous study, it was shown that highly educated people and health professionals were not willing to have their children vaccinated due to the perceived ineffectiveness of the vaccine and its potential side effects [15]. Torun et al. found that $66.1 \%$ of health professionals who were parents had not thought about the vaccination, whereas $12.9 \%$ of them were indecisive. When the reasons for not vaccinating were evaluated, it was noted that $79.8 \%$ of the respondents did not find the vaccine to be reliable, $57.7 \%$ of them did not believe in its efficacy, and
$1.3 \%$ of them stated that they were not vaccinated because the Prime Minister was also not vaccinated [13]. According to the study of the European Respiratory Society (ERS) and European Society of Clinical Microbiology and Infectious Diseases (ESCMID), 35\% of health professionals in their study were not vaccinated. The existence of side effects was the main reason given for not vaccinating [16]. According to the study of Savas et al. on health professionals in Gaziantep, only $12.7 \%$ of the study group was vaccinated and most of them did not believe in the reliability and protectiveness of the vaccine. The reasons for not being vaccinated were found to be fear of side effects, not believing in its efficacy, negative news about the vaccine, and the negative attitude of the Prime Minister regarding the vaccine [3]. In another study, it was reported that 9.6\% of medical faculty and school of health students received the pandemic flu vaccine [17]. In our study, we determined that $53.2 \%$ of the health professionals were not vaccinated. Among the unvaccinated individuals, $46.4 \%$ did not believe in the efficacy of the vaccine. The percentage of individuals affected by the fact that the Prime Minister was not vaccinated was $29.3 \%$. Health professionals were significantly affected by the statements of the Prime Minister. According to the study of Slovic on risk perception, the politicians developing and managing the health policies have to understand the responses and the thoughts of the public about risk. Policies regulated without understanding this may not be effective [18].

Risk perception is understanding the information about risk and danger [19]. The perception of nonspecialist people apart from the scientific and technical view for the risks is not objective [20]. In various studies, different risk perception results have been found $[9,12,21]$. Rubin et al., in their study performed at the beginning of a pandemic, found that the risk perception of the public is very high (21\%) [9]. In their study on 402 university students, Akan et al. reported women's risk perceptions were higher. They did not find a difference in terms of gender in students studying health sciences when they compared the whole group in terms of risk perception. They also found that education had an effect on the difference between the genders [12]. Barr et al. reported that in 200 families surveyed by the New South Wales Department of Health, the risk perception during an avian influenza pandemic was $45.5 \%$ especially for themselves and their families [21]. In our study, we did not find a significant difference between genders 
when we evaluated the risk perception of the study group.

The risk perception of professors and people using their own cars to reach the hospital were significantly higher than those of assistants, nurses, and the individuals who used public transportation. These results suggest that education and socio-economic level has a linear relationship with risk perception. On the other hand, a negative correlation was found between the total knowledge score and behavior score. Although this result seems paradoxical, risk perception decrease causes insecure behaviors as technical knowledge and the sense of control increase [22]. Hand hygiene is the unique and most important parameter that is emphasized most often to prevent the transmission of infections in health care and is one of the standard measures. Hand hygiene includes washing hands with water and soap (normal or with antiseptic) and the use of alcohol-based products [6]. Grayson et al. showed in their study on H1N1 influenza viruses that hand hygiene performed using alcohol-based products or washing hands with water and soap is very effective [23]. A mask is another important protective measure. Masks prevent the spread of infection by protecting the health professional from infected patients, and protecting patients from infected health professionals or other patients [6]. Jefferson et al. researched in their study whether the spread of respiratory route viruses decreases with physical measures [24]. According to this study, hand hygiene, standard surgical masks, N95 masks, coats and gloves reduce the spread of respiratory route viruses. The combined use of these measures is even more effective. In our study, $42.9 \%$ of health professionals were not sure that the standard surgical mask would protect them, and $37.7 \%$ did not believe that a mask would protect them. Among the individuals responding to the questionnaire, $22.1 \%$ did not believe that washing hands with water and soap would protect them, and $27.3 \%$ were undecided. These findings show that there is a significant lack of knowledge among the health professionals even at the level of main protection knowledge. To remedy this lack of knowledge, more education and practical applications are needed.

Our survey could be a helpful resource for decision makers to support programs and campaigns aimed at informing and educating health workers. Some important information regarding obstacles to vaccination has been provided in our survey. The present study has some limitations. First, it was conducted only at our hospital, and had relatively low number of respondents; it does not, therefore, reflect the whole Turkish population. Second, health care staff other than doctors and nurses were not included in the study.

Finally, standard protective measures should be known and applied when there is an outbreak. However, in the information age, though it is easy to access the right information, several confusing information also exists. This confusing information and the attitude of the authorities have negative effects on vaccination ratios. When there is a lack of information, the worries among the health professionals become even greater. For that purpose, the web page of the Ministry of Health is a reliable source of information aside from scientific letters.

\section{References}

1. Treanor JJ (2010) Influenza Viruses, Including Avian Influenza and Swine Influenza. In Mandell GL, Bennett JE, Dolin R, editors. Principles and Practice of Infectious Diseases. Philadelphia: Churchill Livingstone. 2265-2288.

2. Echevarria-Zuno S, Mejia-Arangure JM, Mar-Obeso AJ, Grajales-Muniz C, Robles-Perez E, Gonzalez-Leon M, Ortega-Alvarez MC, Gonzalez-Bonilla C, Rascon-Pacheco RA, Borja-Aburto VH (2009) Infection and death from influenza A H1N1 virus in Mexico: a retrospective analysis. Lancet 374: 2072-2079.

3. Savas E, Tanriverdi D (2010) Knowledge, attitudes and anxiety towards influenza A/H1N1 vaccination of healthcare workers in Turkey. BMC Infect Dis 10: 281.

4. Bautista E, Chotpitayasunondh T, Gao Z, Harper SA, Shaw M, Uyeki TM, Zaki SR, Hayden FG, Hui DS, Kettner JD, Kumar A, Lim M, Shindo N, Penn C, Nicholson KG (2010) Clinical aspects of pandemic 2009 influenza A (H1N1) virus infection. N Engl J Med 362: 1708-1719.

5. Bakir M (2010) Pandemic influenza situation update in Turkey. J Infect Dev Ctries 4: 124-125. doi:10.3855/jidc.690

6. Siegel JD, Rhinehart E, Jackson M, Chiarello L; Health Care Infection Control Practices Committee (2007) 2007 guideline for isolation precautions: preventing transmission of infectious agents in health care settings. A J Infect Control 35 Suppl 2: S65-S164.

7. Damery S, Draper H, Wilson S, Greenfield S, Ives J, Parry J, Petts J, Sorell T (2010) Healthcare workers' perceptions of the duty to work during an influenza pandemic. J Med Ethics 36: 12-18.

8. Jippes E, Achterkamp MC, Brand PL, Kiewiet DJ, Pols J, van Engelen JM (2010) Disseminating educational innovations in health care practice: training versus social networks. Soc Sci Med 70: 1509-1517.

9. Rubin GJ, Amlot R, Page L, Wessely S (2009) Public perceptions, anxiety, and behaviour change in relation to the swine flu outbreak: cross sectional telephone survey. BMJ 339: b2651.

10. Kamate SK, Agrawal A, Chaudhary H, Singh K, Mishra P, Asawa K (2010) Public knowledge, attitude and behavioural changes in an Indian population during the Influenza A (H1N1) outbreak. J Infect Dev Ctries 4: 7-14. doi: $10.3855 /$ jidc. 501 
11. Paek HJ, Hilyard K, Freimuth VS, Barge JK, Mindlin M (2008) Public support for government actions during a flu pandemic: lessons learned from a statewide survey. Health Promot Pract 9: 60S-72S.

12. Akan H, Gurol Y, Izbirak G, Ozdatli S, Yilmaz G, Vitrinel A, Hayran O (2010) Knowledge and attitudes of university students toward pandemic influenza: a cross sectional study from Turkey. BMC Public Health 10: 413.

13. Torun SD, Torun F, Catak B (2010) Healthcare workers as parents: attitudes toward vaccinating their children against pandemic influenza A/H1N1. BMC Public Health 10: 596.

14. Azap A, Bozkurt GY, Temel F, Cakir B, Tezcan S (2011) Vaccination against pandemic influenza A H1N1 among health care workers. Lessons for the next pandemic. Saudi Med J 32: 858-860.

15. Hak E, Schonbeck Y, De Melker H, Van Essen GA, Sanders EA (2005) Negative attitude of highly educated parents and health care workers towards future vaccinations in the Dutch childhood vaccination program. Vaccine 23: 3103-3107.

16. Blasi F, Palange P, Rohde G, Severin T, Cornaglia G, Finch R (2011) Healthcare workers and influenza vaccination: an ERS-ESCMID Web-based survey. Clin Microbiol Infect 17: 1223-1225.

17. Ozer A, Kirecci E, Ekerbicer HC, Celik M (2011) Medical faculty and school of health student knowledge of and behavior regarding swine flu and vaccine, in Kahramanmaras, Turkey. Southeast Asian J Trop Med Public Health 42: 161167.

18. Slovic P (1987) Perception of risk. Science 236: 280-285.

19. Slovic P, Fischhoff B, Lichtenstein S (2007) Rating the risk. In Ragnari EL, editor. The perception of the risk. London: Earthscan Publications. 104-120.
20. Karger CR, Wiedemann PM (1998) [Cognitive and affective components of the judgement of environmental risks]. Z Exp Psychol 45: 334-344.

21. Barr M, Raphael B, Taylor M, Stevens G, Jorm L, Giffin M, Lujic S (2008) Pandemic influenza in Australia: using telephone surveys to measure perceptions of threat and willingness to comply. BMC Infect Dis 8: 117.

22. Akın L, Güler Ç (2006) Halk Sağlı̆̆ Temel Bilgiler. Ankara: Hacettepe Yayınları. 582 p.

23. Grayson ML, Melvani S, Druce J, Barr IG, Ballard SA, Johnson PD, Mastorakos T, Birch C (2009) Efficacy of soap and water and alcohol-based hand-rub preparations against live H1N1 influenza virus on the hands of human volunteers. Clin Infect Dis 48: 285-291.

24. Jefferson T, Del Mar CB, Dooley L, Ferroni E, Al-Ansary LA, Bawazeer GA, van Driel ML, Nair S, Jones MA, Thorning S, Conly JM (2011) Physical interventions to interrupt or reduce the spread of respiratory viruses. Cochrane Database Syst Rev: CD006207.

\section{Corresponding author}

Ömer Evirgen

Department of Infectious Diseases and Clinical Microbiology, Mustafa Kemal University School of Medicine, 31000 Hatay, Turkey

Phone: +90-326 2291000 (ext. 3330)

Fax: +90 3262455654

Email: omerevirgen@mku.edu.tr

Conflict of interests: No conflict of interests is declared. 